\title{
Transit-Oriented Development in the Inner City: A Delphi Survey
}

\author{
Anastasia Loukaitou-Sideris \\ University of California, Los Angeles
}

\begin{abstract}
This study presents the results of a three-round Delphi survey that focused on issues and opportunities related to transit-oriented development (TOD) in U.S. inner cities. The survey queried a panel of 25 experts about the various goals and objectives of the practice of TOD, as well as the preconditions and constraints surrounding such development in economically disadvantaged areas of the inner city. Starting from a wide range of responses, the panel was eventually able, through the Delphi process, to focus on specific issues and propose a concrete set of strategies for the implementation of TODs.
\end{abstract}

\section{Introduction}

Economic development of depressed inner-city areas has long been a goal of local government and city planning. In the 1980s, there was considerable debate regarding the optimal allocation and planned investment of private resources in inner-city neighborhoods that can trigger private economic activity and attendant jobs and tax revenues (Witherspoon 1982). In particular, transportation investments, often utilizing state and federal funds, were viewed as capable of inducing positive change and development in derelict inner-city areas (Cervero 1987).

Over the last decade, city planners and transit officials have promoted the idea of using rail transit stations as instruments of development. Many planners and designers have enthusiastically espoused a transit-oriented transformation 
in urban form. Writings about TOD have proliferated (Calthorpe 1990, 1992; Katz 1994; Bernick and Cervero 1997). TODs are defined as mixed-use communities within a quarter-mile radius of a rail station. Their design configuration and land uses emphasize a pedestrian-oriented environment and reinforce the use of public transportation. A mix of residential, retail, office, open space, and public uses are arranged in comfortable proximity, making it possible for residents and workers to travel by transit, bicycle, or foot (Calthorpe 1993). Such development is often described as a "village" surrounding the transit stop, where a core commercial area provides space for offices and retail. This vision is about an alternative way of life supported by a higher density, pedestrianfriendly, and transit-contingent urban environment.

Transit villages have been described as tools for revitalizing U.S. inner cities (Bernick 1996). In their book Transit Villages for the 21st Century, Bernick and Cervero (1997, pp. 9-10) argue that:

The transit village offers a fresh new approach to stimulating economic growth in inner-city neighborhoods served by rail .... Combining transit village planning with aggressive programs to improve the social and physical infrastructure of neighborhoods can provide a formula for progressive change... Transit villages can be important catalysts to community rebuilding.

Such enthusiasm notwithstanding, substantial social, economic, and institutional barriers persist. Many of the obstacles are rooted in the segregated social ecology of U.S. cities. Inner-city neighborhoods that have often been segmented by freeway development, are now experiencing a new "intrusion," as fixed rail lines have to traverse them to link suburban centers with the downtown (Loukaitou-Sideris and Banerjee 2000). These areas suffer from a long history of disinvestment and neglect. Fear of crime, drugs, gangs, and violence dominate public perception.

Is there a future for "transit villages"-so far considered mainly in the context of middle- and upper-class suburban settings-along the inner-city corridors? What are the constraints and potentials for implementing TOD around inner-city transit stations? 


\section{Rail Transit and Economic Development: Literature Review}

A literature review to respond to the previous questions provides some contradictory arguments. Studies of the 1970 s and early 1980 s have typically found that transportation investments may have some small effects on economic development, but only if certain preconditions are present. Knight and Trygg (1977) have argued that for substantial land-use impacts to occur in the vicinity of a railway station, four factors need to exist simultaneously:

1. local government policies supportive of development;

2. a growing regional economy;

3. availability of developable land around stations; and

4. positive physical characteristics of the station area (good location, compatible land uses, etc.).

Gómez-lbáñez (1985, p. 349) reported that merchants and developers located near light rail lines in San Diego, Calgary, and Edmonton found them to be rather unimportant factors for business activity or development decisions. He argued that for a rail system to produce significant development around station areas three conditions need to be met:

1. The rail system produces a significant improvement in transportation service quality and accessibility.

2. The metropolitan area is growing.

3. There is supportive local zoning.

Knight (1980) claimed that the available evidence did not show that American and Canadian rail rapid transit investments had had any major effects on urban structure or economic development. On the other hand, in a comprehensive study of light rail transit systems in the United States and Canada, Cervero (1984) concluded that the economic stimulus of light rail on urban form can be moderately high when accompanied by a strong regional economy, a prodevelopment policy orientation, zoning, taxation, and joint development incentives, as well as physical improvements that enhance aesthetics and pedestrian access and create hospitable station settings. 
In a study of the impacts of urban rail transit on local real estate markets in two of the fastest-growing cities in the United States in the 1980s, Atlanta and Washington D.C., Cervero and Landis (1993) found that the rail systems had a positive impact on station real estate markets. These impacts included higher rents, lower vacancy rates, and higher densities in office buildings around station areas (Cervero 1994).

In the late 1980s and 1990s, the debate about the effectiveness of transit investments in inducing economic development was revisited. The New Urbanist movement advocated physical layouts, called "pedestrian pockets," where light rail transit was an integral element of the urban form (Kelbaugh 1989; Calthorpe 1993; Katz 1994). The force of these ideas and their promise of urban revitalization convinced many city planners. Since 1990, much-touted design guidelines have sought to shape TOD in the City of San Diego and in Sacramento County (Calthorpe 1990, 1992). In 1993, the most automobileoriented city in the nation, Los Angeles, formulated guiding principles for station-area development (City of Los Angeles Planning Department 1993). TOD is a major component of Los Angeles's long-term growth strategy, as the city's new General Plan calls for directing 75 percent of all new development onto 5 percent of its land, mostly around rail stations and bus stops (Chu and Curtiss 1995). In 1994, the California legislature enacted a transit village bill to promote such planning efforts.

In the 1990s, the subject of TOD found both academic proponents and critics. Proponents (Bernick 1996; Bernick and Cervero 1997) tended to emphasize the opportunities for TOD and transit village development. They noted the growing willingness of transit agencies and local governments to initiate joint development projects near rail stations, receptive policies and legislation for coordinating transit and land-use decisions, and demographic growth of population groups (the elderly, young professionals without children, etc.) that are prime candidates for TOD living (Bernick and Cervero 1997, pp.138-139).

Skeptics have mostly emphasized barriers such as local institutional obstacles (Boarnet and Crane 1998), as well as the behavior of private land 
markets. They have pinpointed the fact that, despite the enthusiasm, residential TOD activity has been rare in practice (Boarnet and Crane 1998). Examining an inner-city line in Los Angeles, Loukaitou-Sideris and Banerjee (2000) found no evidence that it had promoted revitalization and growth in the adjacent neighborhoods. They argued that the New Urbanist's romantic image of a transformed inner city stands in stark contrast with the decay, unemployment, poverty, and crime that characterize these neighborhoods (Loukaitou-Sideris and Banerjee 1996, 2000).

Despite the rhetoric about the potential of New Urbanism to revitalize stark inner-city areas, the few implemented examples of New Urbanist planning are located in outlying suburban areas or have been designed as resort towns that are typically devoid of transit. There has been, however, a notable exception in the works. A $\$ 100$ million redevelopment is currently under construction around the Fruitvale BART station that will bring a mixture of housing, shops, offices, senior center, child care facilities, library, and community centers to this low-income Oakland neighborhood (Wadhawani 1999). The Fruitvale development is the result of intense community activism by the Spanish Speaking Unity Council, a local community group that was able to attract extensive funding from the public sector (Federal Transportation Authority, Housing and Urban Development, Health and Human Services) and private foundations (Hewlett, Irvine, Ford) (Bernick 1996).

Is the Fruitvale example paradigmatic for things to come, or is it a unique case that is unlikely to be repeated elsewhere? What are the prospects for TOD in America's inner cities? In addressing this issue, this article reports on a Delphi survey of knowledgeable transportation planning experts.

\section{The Delphi Research Concept}

The Delphi technique was developed by Norman Dalkey and Olaf Helmer of Rand Corporation in the early 1950s as a means of systematic group judgment (Rawitz 1991). According to Linstone and Turoff (1975, p. 3), Delphi is a "method for structuring a group communication process so that the process is effective in allowing a group of individuals, as a whole, to deal with a complex problem." The belief is that the group's judgment will have more validity, 
and will be more complete and accurate than individual points of view (Dalkey 1972).

Use of a Delphi survey is appropriate when there is lack of consensus or agreement regarding the nature of a problem or the components, which must be included in a successful solution (Rawitz 1991). The Delphi technique has been employed in a variety of different contexts, as its reliance on human judgment makes it useful in decision- and policy-making situations (Cavalli-Sforza et al. 1982).

The goal of the Delphi technique is to bring informed consensus, or at least to delineate, clarify, and define existing opinions and views (Herrick Cramer 1991). This is achieved by an iterative process in the form of two to four rounds of questions. In the first round, the panel responds to the questions posed by the researchers, who, in turn, use statistical measures to summarize the panel's responses. The summaries are fed back anonymously to the panel for the second and subsequent rounds. In these rounds, experts are asked to reconsider their responses based on the information provided to them by the results of the previous round. The goal of the iterative process is "to obtain a convergence of responses to each question. Such convergence would be indicated by the decrease in the measures of dispersion for the responses and by stability of the distribution of the responses to each question" (Cavalli-Sforza et al. 1982, p. 12).

The Delphi process possesses several strengths. It:

- reduces the effect of dominant individuals, by preserving anonymity and eliminating face-to-face communication (Dalkey 1972);

- enables the creation of a heterogeneous group for problem solving (Rawitz 1991);

- encourages "exhaustive search" of issues and opinions; and

- allows for a better opportunity to reach consensus (Rawitz 1991).

In terms of weaknesses, the method pools out extreme views, as consensus is reached by averaging. In addition, the quality of the findings can be affected by a poor (or not representative) selection of the panel, and by a poor summary, analysis, and report of the results of each round. 
The study reported in this article employed a panel of 25 individuals who had knowledge and experience in the field of TOD.' Panel members were identified by means of four criteria:

1. position at a university in the field of transportation planning and/or real estate and economic development ( 7 participants);

2. leading position in a public sector agency involved in TOD ( 6 participants);

3. leading position in a private sector company that has been involved as consultants or developers in TOD (7 participants); and

4. leading position in a nonprofit organization or community group that has been involved in TOD ( 5 participants). ${ }^{2}$

The 25 panel members were from six different states (California, Illinois, Massachusetts, Missouri, Oregon, Pennsylvania) and the District of Columbia, but they have been in involved in TOD planning, design, development, or research for projects in a much wider geographical spectrum. ${ }^{3}$ Individuals who had leading roles in their organization (directors, managers, principals, project managers, senior associates) were sought from the public, private, and nonprofit sectors. This yielded 20 male and 5 female respondents. The racial/cultural breakdown of the panel was: white, 20; African-American, 1; Latino, 1; Asian, 1 ; and undeclared, 2 . While this is certainly not a balanced sample in terms of race or gender, it may be quite representative of the sociodemographics of the group that tends to acquire leading positions in the TOD field.

\section{Findings and Discussion}

During the first round of the Delphi process, participants were told that:

The study seeks to examine TOD in two different ways. It will look at the various goals and objectives underlining the practice of TOD and will also examine the means and problems of its implementation. We are particularly focusing on TODs in North American inner-city areas, and we want to identify the relevant issues, objectives, opportunities, and constraints surrounding such development. By inner city, we mean the economically disadvantaged areas that lie between the downtown district and a city's suburbs. 
Panel members were asked to respond to four open-ended questions:

1. What are the most important goals of TOD?

2. What are the most important objectives of TOD in inner-city areas?

3. What are the most important preconditions for successful TOD in inner-city areas?

4. What are the most important barriers to inner-city development?

The first round yielded various responses from the panel (Table 1) and showed that the concept of TOD is loaded with a variety of expectations that include economic (e.g., generate revenue for the transit authority, the developer, the community), environmental (air quality, sustainability, reduction of sprawl, energy conservation), social (choice, mobility, accessibility, social interaction), and planning (land-use/transportation coordination, regional linkages) goals. Participants stated that, in addition to these goals, inner-city TODs should promote community economic development, enhance safety, create jobs, increase the value of the residential market, reinforce prior public investment, attract more retailers, provide affordable housing, effectively link the inner city with other parts of the metropolitan area, and combat inner-city decline.

Participants listed an array of preconditions for successful inner-city TODs that included economic and market-related factors (federal and state funding, private sector interest, public/private partnerships, and good economic climate), regulatory/institutional factors (collaboration and coordination among different public agencies, proactive planning departments and transit agencies, political support, and community involvement), as well as urban form and transit characteristics conducive to TOD. The list of responses to the last question was the longest-an indication of how difficult it is to establish TODs in U.S. inner cities. Participants discussed a wide spectrum of barriers to such development, including economic, social, and institutional constraints.

The first round did not involve any prioritization of responses. However, in the second round, the panel was asked to select and rank the 10 items they felt were the most important per question. Responses that received a very low score were eliminated. This reduced the range of answers considerably (Table 2). In this round, three experts—all from academia-felt strongly that the TOD concept could not be successful in achieving its goals or significantly influ- 


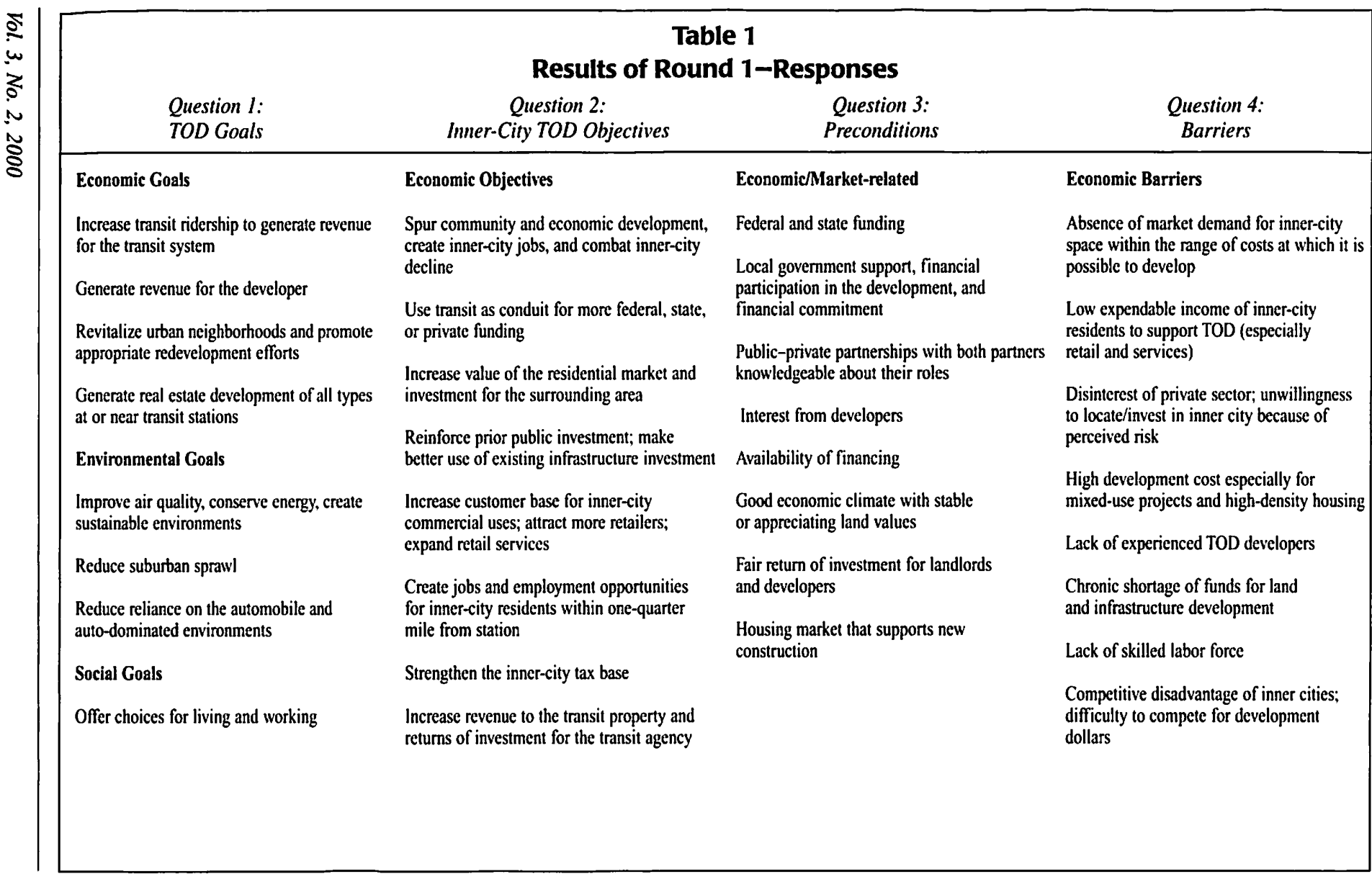




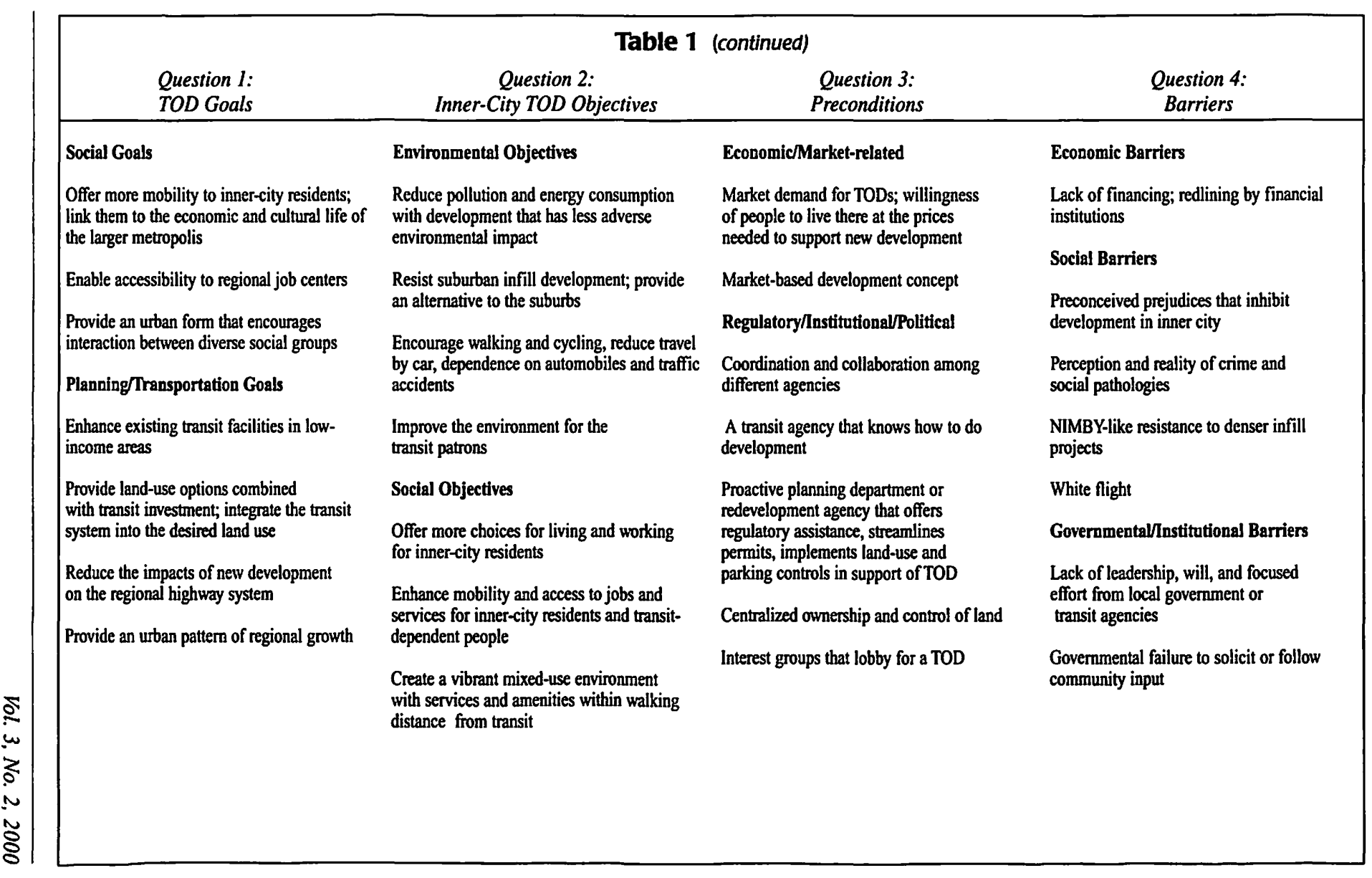




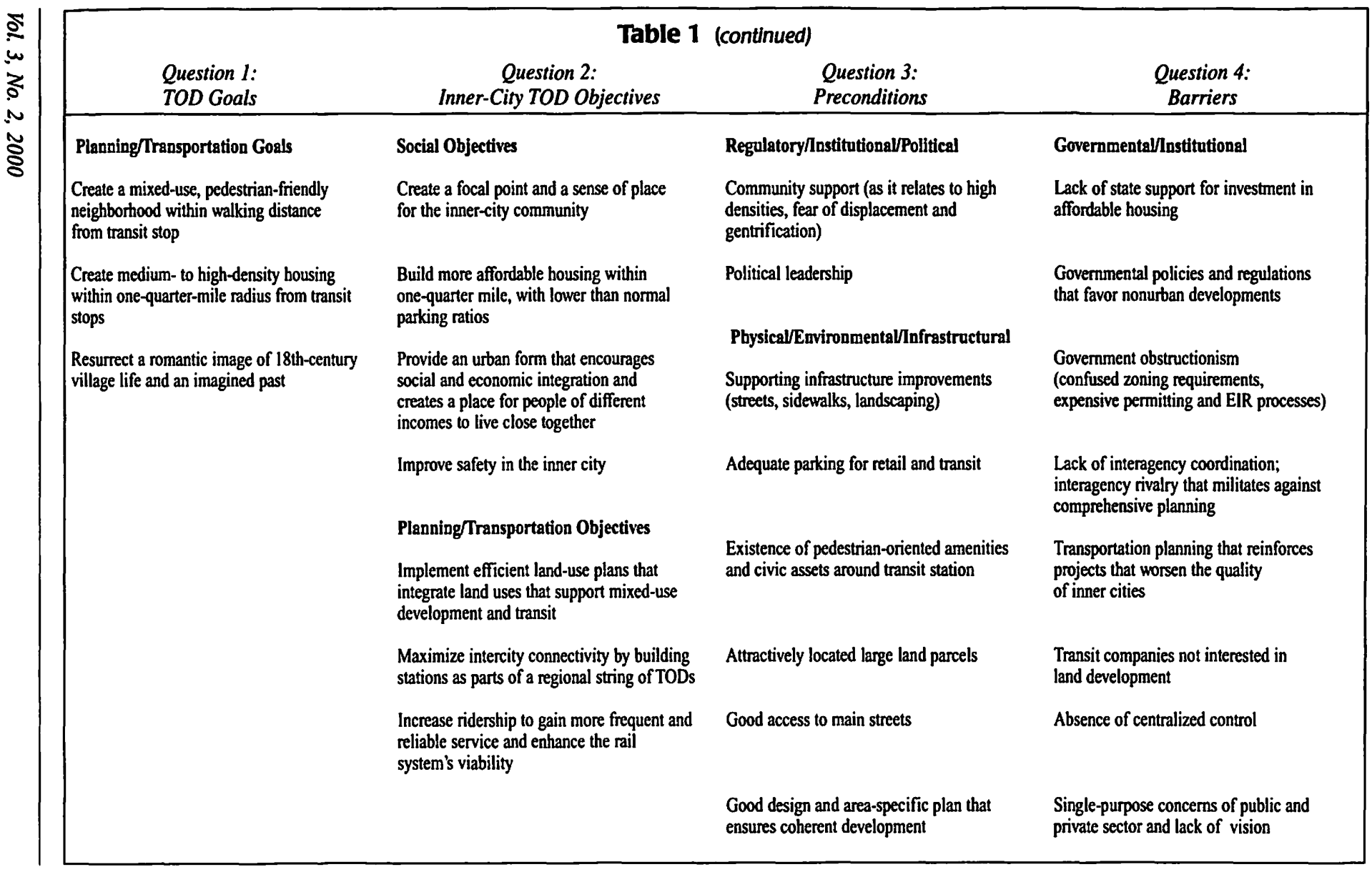




\section{Table 1 (continued)}

Question 1: TOD Goals

Question 2: Inner-City TOD Objectives

Question 3:

Preconditions

Question 4: Barriers
Physical/Environmental/Infrastructural

Security and perception of safety good inner-city schools and day care

\section{Transit-Related}

A critical mass of transit-dependent population

A transportation and development policy that is multimodal and recognizes the connection between land use and transport

Transit system alignment that services desirable locations for housing development

Reliable and frequent transit service
Physical/Environmental/Infrastructural Barriers

Pollution and contaminated sites

Ubiquitous road network that vitiates against selected points of high accessibility at transit stops

Lack of large sites; difficult land assembly

Incompatible land uses for residential development

Lack of quality schools and amenities

Inadequate and declining infrastructure

Long lead time for infrastructure investments

\section{Other Barriers}

High car and home ownership rates

Negative image/attitude toward transit service 
encing urban life. One panelist argued, "TOD is a hopeless waste that can divert resources from other more worthwhile projects." This response was included in the survey of round 2, but was eliminated from round 3 , receiving a very low score. Subsequently, one of the three panelists decided to stop participating in the Delphi process, while the other two stayed on. ${ }^{4}$

To identify the most significant issues, preconditions, and constraints related to TODs, a third survey was sent to participants during round 3 . This survey asked the panel to select and rank the five most important responses to each question. Responses that received an average score of less than 2.0 were eliminated. Table 3 shows the respondents' priority ranking and scores. Additionally, respondents were encouraged to discuss possible strategies, policies, and actions that could counteract the perceived barriers to inner-city TOD.

Even though there was no unanimous agreement, the panel was able to effectively identify the five or six most important issues and concerns for each question. Considering that the first round had generated 20 to 30 responses per question, this was a considerable accomplishment.

Experts agreed that the major goal of a TOD is to create a mixed-use, pedestrian-friendly neighborhood within walking distance from a transit stop that offers choices for living and working, reduces automobile dependence, effectively integrates land use and transportation, and increases transit ridership and revenue for the transit system. This is a rather broad statement that could have been easily drawn from the Charter for New Urbanism (see Kelbaugh 1997). As shown in Table 3, experts felt that for inner-city areas, three additional social and economic objectives should take precedence: (1) community and economic development, (2) mobility and accessibility to jobs and services, and (3) reinforcement of prior public investment. In other words, the panel believed that TOD in inner-city areas should have the objective to act as a catalyst, combat inner-city decline, and bring about positive change.

The panel argued that successful TOD cannot be carried out by only one entity but needs the successful collaboration, financial support, and regulatory assistance of public agencies, local government, and the private sector; support of the local community; and interest from perspective consumers (market demand). But these preconditions are often not met in the inner cities because 


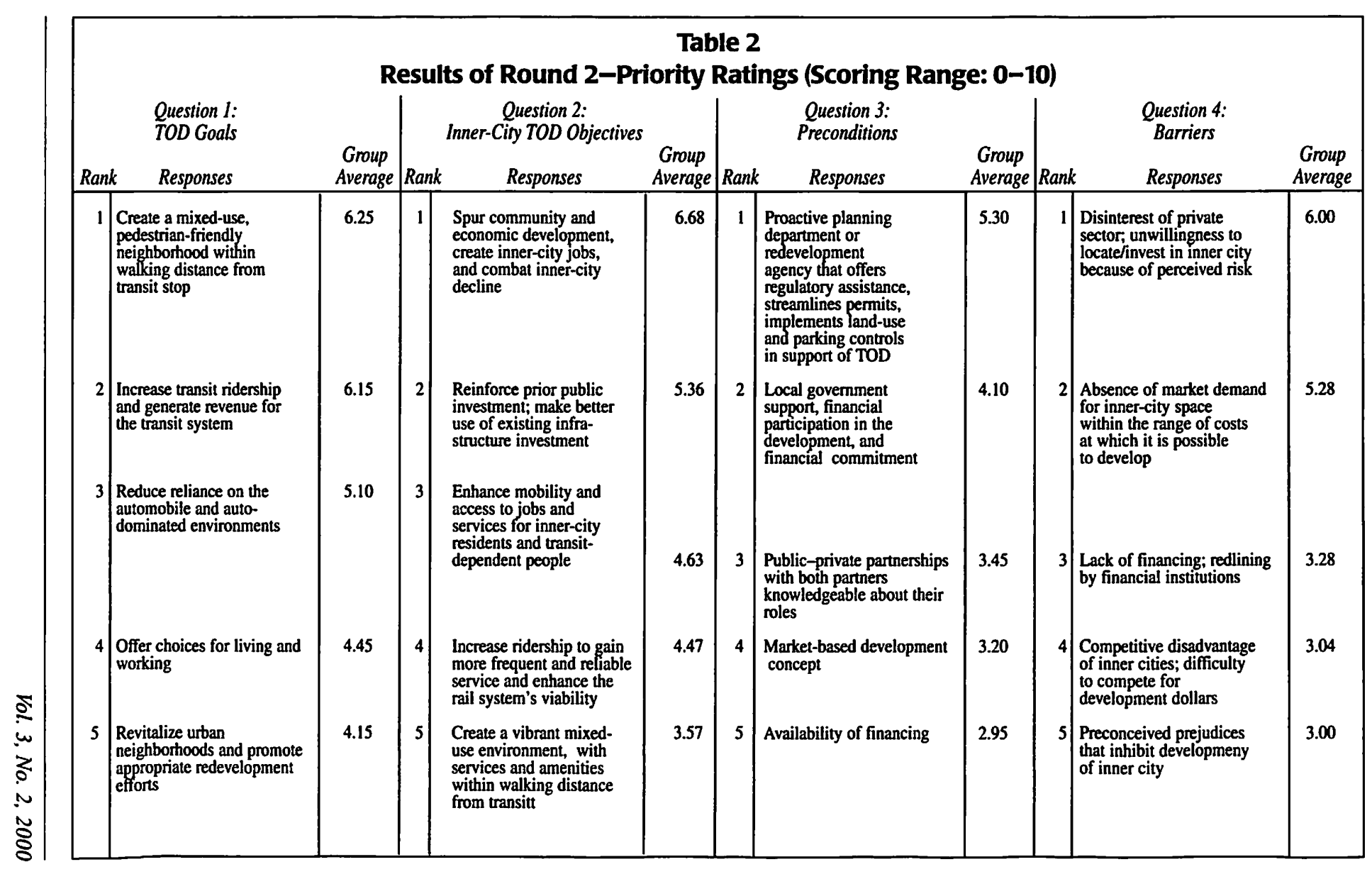




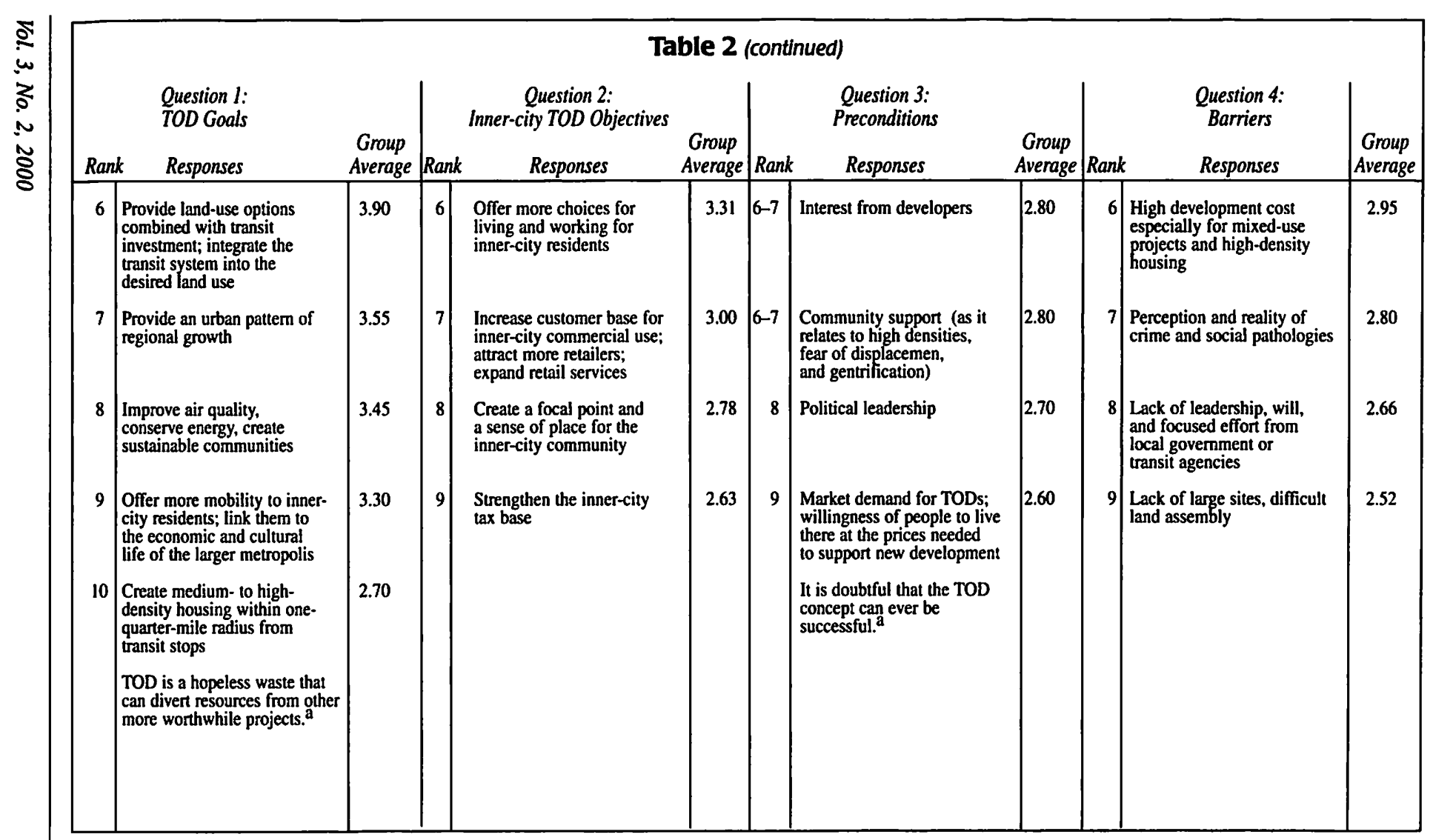

a. No score. Response added in the second round by one participant. 


\begin{tabular}{|c|c|c|c|c|c|c|c|c|c|c|c|}
\hline & Results of & bund 3 & 3-Pr & riority Ratings fo & $\begin{array}{r}\text { Tab } \\
\text { the Fil }\end{array}$ & ve $\mathbf{M}$ & Most Important Issu & ues (Sc & corir & ng Range: 0-5) & \\
\hline & $\begin{array}{l}\text { Question l: } \\
\text { TOD Goals }\end{array}$ & & & $\begin{array}{c}\text { Question 2: } \\
\text { Inner-City TOD Objectiv }\end{array}$ & & & $\begin{array}{l}\text { Question 3: } \\
\text { Preconditions }\end{array}$ & & & $\begin{array}{l}\text { Question 4: } \\
\text { Barriers }\end{array}$ & \\
\hline Rank & Responses & $\begin{array}{c}\text { Group } \\
\text { Average } \\
\end{array}$ & Rank & Responses & $\begin{array}{c}\text { Group } \\
\text { Average } \\
\end{array}$ & Rank & Responses & $\begin{array}{c}\text { Group } \\
\text { Average }\end{array}$ & Rank & Responses & $\begin{array}{c}\text { Group } \\
\text { Average }\end{array}$ \\
\hline $1 \mid \begin{array}{l}c \\
p \\
n \\
d\end{array}$ & $\begin{array}{l}\text { Create a mixed-use, } \\
\text { pedestrian-friendly } \\
\text { neighbortood within walking } \\
\text { distance from transit stop }\end{array}$ & 4.1 & $1 \mid \begin{array}{l}s \\
e \\
c \\
a \\
d\end{array}$ & $\begin{array}{l}\text { Spur community and } \\
\text { economic development, } \\
\text { create inner-city jobs, } \\
\text { and combat inner-city } \\
\text { decline }\end{array}$ & 4.2 & 1 & $\begin{array}{l}\text { Proactive planning } \\
\text { development or redevelop- } \\
\text { ment agency that offers } \\
\text { regulatory assistance, } \\
\text { streamlines permits, imple- } \\
\text { ments land-use and parking } \\
\text { controls in support of TOD }\end{array}$ & 3.6 & 1 & $\begin{array}{l}\text { Disinterest of private sector, } \\
\text { unwillingness to locate/ } \\
\text { invest in inner city because } \\
\text { of perceived risk }\end{array}$ & 4.5 \\
\hline 2 & $\begin{array}{l}\text { Increase transit ridership } \\
\text { and generate revenue for } \\
\text { the transit system }\end{array}$ & 3.5 & $2 \mid \begin{array}{l}\mathrm{f} \\
\mathrm{a} \\
\mathrm{f} \\
\mathrm{t}\end{array}$ & $\begin{array}{l}\text { Enhance mobility and } \\
\text { access to jobs and services } \\
\text { for inner-city residents and } \\
\text { transit-dependent people }\end{array}$ & 3.4 & 2 & $\begin{array}{l}\text { Local government support, } \\
\text { financial participation in the } \\
\text { development, and financial } \\
\text { commitment }\end{array}$ & 3.0 & 2 & $\begin{array}{l}\text { Absence of market demand } \\
\text { for inner-city space within } \\
\text { the range of costs at which } \\
\text { it is possible to develop }\end{array}$ & 3.5 \\
\hline $4 \mid \begin{array}{l}1 \\
\vdots \\
i \\
5\end{array}$ & $\begin{array}{l}\text { Provide land-use options } \\
\text { combined with transit } \\
\text { investment; integrate the } \\
\text { transit system into the } \\
\text { desired land use }\end{array}$ & 2.6 & $4 \begin{array}{l}4 \\
n \\
5 \\
5\end{array}$ & $\begin{array}{l}\text { Increase ridership to gain } \\
\text { more frequent and reliable } \\
\text { service and enhance the } \\
\text { rail system's viability }\end{array}$ & 2.8 & 4 & Interest from developers & 2.7 & 4 & $\begin{array}{l}\text { Preconceived prejudices that } \\
\text { inhibit development of } \\
\text { inner city }\end{array}$ & 2.6 \\
\hline 5 & $\begin{array}{l}\text { Reduce reliance on the } \\
\text { automobile and auto- } \\
\text { dominated environments }\end{array}$ & 2.2 & $5 \mid \begin{array}{l}c \\
\mathrm{e} \\
\mathrm{a} \\
\mathrm{d}\end{array}$ & $\begin{array}{l}\text { Create a vibrant mixed- use } \\
\text { envisonment, with services } \\
\text { and amenities within walking } \\
\text { distance from transit }\end{array}$ & 2.3 & $5-6$ & $\begin{array}{l}\text { Community support (as it } \\
\text { relates to high densities, fear ) } \\
\text { of displacement, and gentrification } \\
\text { Market demand for TODs; } \\
\text { willingness of people to live } \\
\text { there at the prices needed to } \\
\text { support new development }\end{array}$ & 2.6 & 5 & $\begin{array}{l}\text { Lack of financing; } \\
\text { redlining by financial } \\
\text { institutions }\end{array}$ & 2.3 \\
\hline
\end{tabular}


the private sector is disinterested to invest there, and major retailers are afraid to move in. As one panel member, who is in charge of real estate acquisition for a major supermarket chain, stated, "The potential for high volumes are easily achieved in the inner city, but low productivity and high shrink [theft of product] reduces profits on sales." Thus, real risks along with preconceived prejudices lead to lack of financing and inhibit development of inner-city sites. This creates a competitive disadvantage of the inner cities that find it difficult to compete for development dollars. In addition to the lack of private sector interest for the development of commercial space, panel members pointed out that there is an absence of market demand for inner-city residential space within the range of costs at which it is possible to develop. Because mixed-use development is more expensive than conventional construction, residential units are not affordable for many inner-city residents, while more affluent citizens are not interested in moving to the inner cities.

\section{Creating TOD in the Inner City: Proposed Strategies and Actions}

This is a very strong development time and due to a number of positive aspects, such as low interest rates and good market acceptance for less conventional, newer prototypes, it is time to move the vision into reality. In my opinion, this is the best time in 50 years to shape our communities with urban form different from the post-World War II suburban sprawl.

\section{-Delphi participant}

The passage from vision to reality is not easy. Studies have shown that even in good economic times, a transit line cannot, by its mere presence, catalyze a miracle in the inner city (Loukaitou-Sideris and Banerjee 2000). Development and positive change in an environment that has remained disinvested in and neglected for decades requires specific and drastic actions, coordinated policies, and concrete strategies. As shown in Table 3 (question 4), the panel found five major impediments to implementing TOD around inner-city stations:

1. disinterest of the private sector to locate and invest in the inner city;

2. absence of a market demand from the part of the public that can afford to pay the arguably higher cost entailed in a mixed-use development; 
3. competitive disadvantage of the inner city;

4. preconceived prejudices regarding inner-city locations; and

5. lack of financing for inner-city locations.

Participants were asked to outline proposals that can help counteract these barriers that TODs face in inner-city environments.

\section{Inducing Private Sector Interest}

Some panelists argued that local communities, planning departments, and redevelopment agencies should do a better job in marketing a neighborhood's commercial strengths so as to attract private developers and retailers to the inner city. Despite stereotypical images of distressed economic landscapes, inner cities can provide certain advantages to investors that are missing from downtown and suburban locations (Porter 1996). Inner-city commercial strips are usually characterized by an abundance of available commercial space, and lower commercial rents and land values than those encountered in outlying locations. Despite low incomes, inner-city high densities translate into a consumer market with substantial purchasing power. Inner cities are often underserved in retailing and services, which also creates opportunities for incoming businesses to fill the void. Despite these advantages, panelists felt that local governments need to assume part of the investment risk and give incentives to developers and retailers to locate in the inner city. Some panelists proposed rent subsidies, while others believed that the public sector should seek to provide some exclusivity for a time period to ensure the success of the incoming commercial development. As one participant reasoned, "The ability to have control of the market for a time period shall enhance the success of the project and after completion would spur future developments based on its success."

Panelists felt that developers will be attracted if the cost of development is effectively lowered. Development of inner-city sites often requires added costs for land assembly and for clearance of toxic pollutants from the soil. Mixed-use developments are more expensive because the cost of code compliance is greater than in conventional single-use projects. The role of the public sector is, once again, crucial in offsetting some of these costs. Public agencies may put together a program of land assembly and land write-down, or become 
partners in projects to reduce costs. They can offer administrative and regulatory assistance, help expedite development approvals, limit special charges and impact fees, and be flexible in certain code requirements. One participant optimistically stated, "Once the fundamental issues of cost are overcome, the developers and lenders will be there."

\section{Building Market Demand for TOD Housing}

A preliminary market research could help identify market needs and impediments. There may be some demand for inner-city housing - some experts felt that it may consist of aging baby boomers who are tired of their long commutes and want a more "urban" experience. Others believed that young professionals or the elderly might be more likely to "experiment" with inner-city living. Market research should identify the demands in rental and for-sale housing and match the proposed development to the economic realities of the area. As any housing expert would argue, housing decisions are made not only on the basis of quality of the housing unit, but are greatly influenced by the quality and number of neighborhood amenities and the condition of surroundings. Many in the panel stressed the importance of "good schools, less crime, improved infrastructure, and cleaner environment." One participant argued, "Beyond actual safety the perception of safety also matters. This means well-lit areas, unobstructed lines of sight, clean sidewalks, and public spaces." All these translate into a considerable investment and subsidies from the public sector. One expert proposed the use of regional tax sharing for school improvement and crime reduction, as well as the direction of increased revenues from changes in federal mortgage deductions ${ }^{5}$ to accelerate brownfield redevelopment, acquire open spaces, and improve transit and its surrounding environment.

\section{Reducing the Competitive Disadvantage}

Inner cities' competitive disadvantage is exacerbated by public policy. As one participant explained, the public sector should "create a more balanced playing field through land-use policy and other pricing mechanisms so that TOD can become competitive to ex-urban development, which is perceived as having lower risks and costs." In reality ex-urban developments create social costs that are rarely borne by the development community. This panelist 
advised that counties force ex-urban developments to pay more realistic impact fees, and states and regions initiate legislation that establishes "Smart Growth" plans with a diverse supply of housing. Key changes in tax reform can also encourage high-density housing in urban areas.

\section{Addressing Preconceived Prejudices}

The absolute need to demonstrate success in inner-city TOD was stressed by many panelists as a means to address fear and skepticism. One participant reasoned, "If a market exists, jumpstarting a few good projects can create a buzz and positive images to counteract the negativity and prejudice that surrounds inner-city living." Others suggested that transportation or redevelopment agencies find communities interested in demonstration projects and work closely with them toward the realization of a successful plan.

While TODs are sometimes inhibited by NIMBYism in suburban communities (Deakin, Bernick, and Chang 1992), fears of gentrification are often prevalent in inner cities. Policies to address such neighborhood concerns should include an educational process and public discourse, as well as the involvement of community members in all stages of the process.

\section{Ensuring Financing}

Redlining has historically plagued inner-city areas. But this problem can now be seen as an opportunity because banks now have new requirements to show lending in low-income communities. According to one participant, "Bank mergers are another opportunity, since the acquiring institution often needs to demonstrate a commitment to investments in neighborhoods which have been overlooked by existing banks." Another source of financing can come from local housing assistance programs that can be targeted to a TOD project to guarantee the revenues needed to justify a conventional loan. In certain cases, local and state agencies can make the needed financial contribution and become part owners, as has happened in the Del Norte Place project on BART. Finally, federal money from the Intermodal Surface Transportation Efficiency Act and its successors can contribute funding. 


\section{Conclusions}

This discussion has clearly demonstrated that there are many pieces that need to be in place for TOD to succeed in the inner city. While local communities and the private sector are certainly actors in the process, it is really the public sector that is asked to take the lead, set the stage, develop policies, and offer important subsidies and assistance to support the creation of TOD in the inner city. The actions of the public sector are influenced to a great extent by the attitudes of the public, since it is taxation that defines public revenue. It remains to be seen if TOD will become a viable option for community enhancement and positive change in America's inner cities.

\section{Acknowledgments}

The author gratefully acknowledges the following individuals who graciously accepted her invitation to participate in the Delphi process and offered valuable insights to this study: Michael Bernick, Marlon Boarnet, Carlos Castellanos, Elisabeth Deakin, Robert Dunphy, Doug Farr, Todd Fontanella, Karen Heit, Anish Kumar, John Landis, Jackie Leavy, Terry Margerum, Alvin McNeal, Val Menotti, Susan Moses, George Ray, Jonathan Richmond, Doug Shoemaker, Tom Shrout, Sarah Smith, Matt Taecker, Martin Wachs, Melvin Webber, Phil Whitemore, and Richard Willson.

The author also thanks her graduate research assistants Laura Aldrete, Lauren Nackman, and Liette Gilbert, who helped with the logistics of the Delphi process.

\section{Endnotes}

1. Many participants stated that they had one or more of the following professional affiliations: American Planning Association, American Institute of Certified Planners, International Society of City and Regional Planners, American Collegiate Schools of Planning, American Institute of Architects, American Economic Association, Association for Public Policy Analysis and Management, Congress of New Urbanism, Regional Science Association International, Transportation Research Board, Institute of Transportation Engineering, Urban Land Institute, Western Regional Science Association, Women's Transportation Seminar, Society of Hispanic Professional Engineers. 
2. This distribution reflected the present employment status of the participants. Many of them had worked under various capacities in the past.

3. Delphi participants listed the following areas where they have been involved in TOD work: Anaheim, Atlanta, Bayonne, Beavertown, Boston, Boulder, Broomfield, Chicago, Cincinnati, Dallas, Denver, Grensham, Hayward, Hoboken, Holyoke, Japan, Jersey City, Long Beach, Los Angeles, Madison, Marin County, Milwaukee, Orange County, Philadelphia, Philippines, Phoenix, Portland, Riverside County, Sacramento, San Bernardino County, San Diego, San Jose, San Francisco, Seattle, Somerville, Sonoma County, South Amboy, Stockton, St. Louis, Toronto, Washington, D.C., Weehawken, Union City, Vancouver.

4. In general, academic participants were more skeptical about the merits or desirability of TOD development than the other three groups.

5. This Delphi participant proposed the elimination of federal mortgage interest deductions for households with incomes over $\$ 250,000$ and the use of this revenue for inner-city improvements.

\section{References}

Bernick, M. 1996. Transit villages: Tools for revitalizing the inner city. Access 9: 13-17

Bernick, M., and R. Cervero. 1997. Transit villages in the 21st century. New York: McGraw Hill.

Boarnet, M., and R. Crane. 1998. Public finance and transit-oriented planning: New evidence from southern California. Journal of the American Planning Association 17(3): 206-219.

Calthorpe, P. 1993. The next American metropolis: Ecology, communities, and the American dream. New York: Princeton Architectural Press.

Calthorpe, P. and Associates. 1990. Design guidelines/final public review draft for Sacramento County Planning Community Development Department.

-1992. City of San Diego land guidance system. Design guidelines/final public review draft. 
Cavalli-Sforza, V., L. Ortolano, J. Dajani, and M. Rosso. 1982. Transit facilities and land use: An application of the Delphi method. Stanford: Stanford University, Department of Civil Engineering, Report IPM-15.

Cervero, R. 1984. Light rail transit and urban development. Journal of the American Planning Association 50(2): 133-147.

- 1987. Transportation and urban development perspectives for the nineties. Berkeley: University of California, Berkeley, Institute of Urban and Regional Development, Working Paper \#470.

-. 1994. Rail transit and joint development. Journal of the American Planning Association 60(1): 83-94.

Cervero, R., and J. Landis. 1993. Assessing the impacts of urban rail transit on local real estate markets using quasi-experimental comparisons. Transportation Research A 27(A:1): 13-22.

Chu, H., and A. Curtiss. 1995. Making way for transit town. Los Angeles Times, March 19: A3.

City of Los Angeles, Department of City Planning. 1993. Land Use/ Transportation Policy. Council File No. 93-0478, City Plan Case No. 93-0257.

Dalkey, N. 1972. Studies in the quality of life: Delphi and decision-making.

Deakin, E., M. Bernick, and T. Chang. 1992. Implementation of residential development at rail transit stations in California: Case studies and policy options. Sacramento: California Department of Transportation, Division of Transportation Planning.

Gómez-Ibáñez, J. 1985. Dark side to the light rail? Journal of the American Planning Association 51(3): 337-351.

Herrick Cramer, R. 1991. The education of gifted children in the United States: A Delphi survey. Gifted Child Quarterly 35(2): 84-90.

Katz, P. 1994. The new urbanism: Toward an architecture of community. New York: McGraw Hill.

Kelbaugh, D., ed. 1989. The pedestrian pocket book: A new suburban design strategy. New York: Princeton Architectural Press. 
-. 1997. Common place. Washington: University of Washington Press.

Knight, R. 1980. The impact of rail transit on land use: Evidence and a change of perspective. Transportation 9: 3-16.

Knight, R., and L. Trygg. 1977. Evidence of land-use impacts of rapid and transit systems. Transportation 6: 231-247.

Linstone, H. A., and M. Turoff, eds. 1975. The Delphi method: Techniques and applications. Reading, MA: Addison Wesley.

Loukaitou-Sideris, A., and T. Banerjee. 1996. There's no there there: Or why neighborhoods don't readily develop near light-rail transit stations. Access 9: 2-6.

-. 2000. Blue line blues: Why the vision of transit village may not materialize despite impressive growth in transit ridership. Journal of Urban Design, forthcoming.

Porter, M. 1996. The competitive advantage of the inner city. Center for Urban Policy Report 7(2): 6.

Rawitz, C. Z. 1991. Minority students and journalism education: A model program design using the Delphi technique. University of California: Los Angeles, Department of Education, Ph.d. diss.

Wadhawani, A. 1999. Unique BART plan renewing Fruitvale. San Francisco Examiner, July 11.

Witherspoon, R. 1982. Transit and urban economic development. in Levinson, H. S. and R. A. Weant (eds.) Urban transportation: perspectives and prospects. Westport, CT: Eno Foundation for Transportation.

\section{About the Author}

ANASTASIA LOUKAITOU-SIDERIS (sideris@ucla.edu) is associate professor in the Department of Urban Planning at the UCLA School of Public Policy and Social Research. She specializes in urban design, physical, and land-use planning. Professor Loukaitou-Sideris is the coauthor of Urban Design Downtown: Poetics and Politics of Form (University of California Press, 1998). 